\title{
Efficiency of Utilization of Soy Protein Isolate in Japanese Young Men
}

\author{
Ming-Fu Wang, ${ }^{1}$ Kyoichi KISHI, ${ }^{1}$ Tetsuzo TAKAHASHI, ${ }^{2}$ \\ Tatsushi KomATsu, ${ }^{1}$ Masaharu OHNAKA, ${ }^{1}$ \\ and Goro INOUE ${ }^{1}$ \\ ${ }^{1}$ Department of Nutrition, School of Medicine, \\ The University of Tokushima, \\ 3-Kuramotocho, Tokushima 770, Japan \\ ${ }^{2}$ Institute of Health and Sports Science, \\ The University of Tsukuba, \\ Sakura-mura, Niihari-gun, Ibaraki 305, Japan
}

(Received November 29, 1982)

Summary The nutritional quality of soy protein isolate (SPI) was evaluated in young men by the nitrogen balance method using fish protein as a standard. Twenty-one male university students were given SPI (Supro 620, Ralston Purina Co., St. Louis, Mo., U.S.A.), fish protein (cod fish) or a 50:50 mixture of the two proteins as the sole source of protein. SPI and fish were prepared as paste products (kamaboko). Four experimental periods were used in which each subject received $0.35,0.45,0.55$ and $0.65 \mathrm{~g}$ protein $/ \mathrm{kg} /$ day, respectively, given in random order. Each period consisted of one day on protein-free diet and ten days on the experimental diet, with an interval of three days on a free-choice (ad libitum) diet between periods. Energy intake was constant for each individual to maintain their body weight $(44.6 \pm 2.4 \mathrm{kcal} / \mathrm{kg} /$ day $)$. The linear regression equations obtained between nitrogen intake $(X: \mathrm{mg} \mathrm{N} / \mathrm{kg} /$ day $)$ and the apparent nitrogen balance $(Y: \mathrm{mg} \mathrm{N} / \mathrm{kg} /$ day) were as follows: SPI, $Y=$ $0.298 X-35.2$; fish protein, $Y=0.365 X-31.8$; mixed protein, $Y=$ $0.423 X-38.3$. The nitrogen requirement for maintenance of nitrogen equilibrium determined from the regression equation was $118.1 \pm$ $15.4 \mathrm{mg} \mathrm{N} / \mathrm{kg} /$ day for SPI, $87.1 \pm 17.2 \mathrm{mg} \mathrm{N} / \mathrm{kg} /$ day for fish protein and $90.5 \pm 17.1 \mathrm{mg} \mathrm{N} / \mathrm{kg} /$ day for mixed protein. The NPUs calculated at the respective maintenance nitrogen intakes were $38.9,52.8$ and 50.8 for SPI, fish protein and mixed protein, respectively. There was no significant difference between the nutritive values of mixed protein and fish protein. The nutritive value of SPI relative to fish protein was estimated as $82 \%$, $74 \%$ and $74 \%$ by the slope-ratio method, and values for the nitrogen requirement and NPU, respectively.

${ }^{1}$ 王 銘富, ${ }^{1}$ 岸 恭一, ${ }^{2}$ 高橋徹三, ${ }^{1}$ 小松龍史, ${ }^{1}$ 大中政治, ${ }^{1}$ 井上五郎 
Key Words soy protein isolate, fish protein, soy-fish mixed protein, nitrogen requirement, slope-ratio method, NPU

In Japan, soybean is an important traditional food item together with rice and fish, and serves as a good source of protein. Soybean is eaten in various forms such as miso (fermented soybean paste), soy sauce, tofu (soybean curd) and natto (fermented soybean product) as well as simply as cooked soybeans. In 1977, protein intake from soybean was estimated to be $7.6 \mathrm{~g} /$ person/day, corresponding to be about $10 \%$ of the total daily protein intake of Japanese. In contrast, the primary use of soybeans in the United States is for oil and the residual meal after extraction of oil is used as animal feed or fertilizer.

With advances in food technology, new soybean products have been introduced, such as soybean flours, concentrates and isolates. In recent years, the consumption of soybean products in a variety of food industries has increased rapidly for economic reasons and because of the multiple functional properties of these products such as for gelation, increase in viscosity, emulsification, dough formation, aeration, and improvement of texture (1). Soy protein isolates are used in processed meat, fish paste products (kamaboko, chikuwa, fish sausages), bakery products and dairy-type products. They are also used as protein supplements in infant formulas and hospital diets.

Besides having wide applications for use in processed foods because of their unique functional properties, soy protein isolates like other vegetable proteins have advantages over animal proteins with respect to lipid metabolism(2). Moreover their nutritional value is important, because protein malnutrition is a world-wide problem and a plentiful supply of cheap high quality protein foods is urgently required to meet the needs of the rapidly growing world population. Although soy protein has a low content of sulfur-containing amino acids, it is considered to be a good quality vegetable protein.

Thus in view of the growing use of soybeans in human foods and the importance of soy protein in protein nutrition, we studied the nutritional value of soy protein isolate and its minimum requirement for apparent nitrogen equilibrium compared with those of fish protein. We also examined the improvement of the nitrogen balance achieved by mixing an equal amount of fish protein with soy protein isolate. Anthropometric measurements as well as hematological examinations and urinalyses were conducted in an attempt to detect possible changes in body composition and metabolic status of the subjects.

\section{MATERIALS AND METHODS}

Three series of experiments using soy protein isolate, fish protein and a mixture of the two proteins as protein source were conducted on 21 male university students. The characteristics of the subjects are shown in Table 1 . The subjects were all 
Table 1. Characteristics of the subjects.

\begin{tabular}{|c|c|c|c|c|c|}
\hline & Subject & $\begin{array}{c}\text { Age } \\
\text { (year) }\end{array}$ & $\begin{array}{c}\text { Height } \\
(\mathrm{cm})\end{array}$ & $\begin{array}{l}\text { Weight } \\
(\mathrm{kg})\end{array}$ & $\begin{array}{c}\text { Blood pressure } \\
\text { (systolic/diastolic) } \\
\text { (mmHg) }\end{array}$ \\
\hline \multirow{7}{*}{ SPI } & $\mathbf{M}$ & 21 & 173 & 68.2 & \\
\hline & $\mathrm{N}$ & 21 & 161 & 53.9 & \\
\hline & $\mathrm{O}$ & 28 & 164 & 54.6 & \\
\hline & $P$ & 22 & 164 & 74.0 & \\
\hline & Q & 26 & 174 & 77.5 & \\
\hline & Mean & 24 & 167 & 65.6 & \\
\hline & $\mathrm{SD}$ & 3 & 6 & 10.9 & \\
\hline \multirow{10}{*}{ Fish } & A & 21 & 171 & 63.3 & $125 / 75$ \\
\hline & B & 20 & 164 & 56.5 & $135 / 82$ \\
\hline & $\mathrm{C}$ & 19 & 171 & 58.1 & $145 / 90$ \\
\hline & $\mathrm{D}$ & 24 & 171 & 69.8 & $120 / 75$ \\
\hline & $\mathrm{E}$ & 22 & 179 & 64.3 & $115 / 75$ \\
\hline & $\mathrm{F}$ & 22 & 172 & 63.2 & $130 / 85$ \\
\hline & $\mathrm{G}$ & 20 & 168 & 57.6 & $120 / 70$ \\
\hline & $\mathrm{K}$ & 22 & 166 & 71.6 & $125 / 84$ \\
\hline & Mean & 21 & 170 & 63.1 & $127 / 80$ \\
\hline & $\mathrm{SD}$ & 2 & 5 & 5.6 & $10 / 7$ \\
\hline \multirow{10}{*}{ Mix. } & A & 21 & 171 & 63.4 & $105 / 70$ \\
\hline & B & 21 & 164 & 59.2 & $133 / 92$ \\
\hline & $\mathrm{C}$ & 20 & 170 & 59.4 & $148 / 93$ \\
\hline & $\mathrm{D}$ & 24 & 171 & 68.3 & $118 / 75$ \\
\hline & $\mathrm{E}$ & 22 & 178 & 62.3 & $122 / 73$ \\
\hline & $\mathrm{H}$ & 25 & 170 & 60.3 & $95 / 58$ \\
\hline & I & 21 & 166 & 52.0 & $108 / 72$ \\
\hline & $\mathbf{J}$ & 21 & 168 & 61.0 & $117 / 83$ \\
\hline & Mean & 22 & 170 & 60.7 & $118 / 77$ \\
\hline & $\mathrm{SD}$ & 2 & 4 & 4.6 & $17 / 12$ \\
\hline
\end{tabular}

healthy and lived in a metabolic ward of our laboratory throughout the study. During the feeding period, they continued their daily routine activities and their physical activities were roughly measured with a pedometer. Subjects $C$ and D could not participate in one of four experimental periods with fish protein because of febrile upper respiratory infections.

The experimental design is shown in Fig. 1. After a four-day adjustment period during which subjects were given $1.25 \mathrm{~g} / \mathrm{kg}$ of protein and maintenance energy from conventional foods, each subject received four low levels of protein successively. Subjects were randomly assigned to each low protein level according to the Latin 


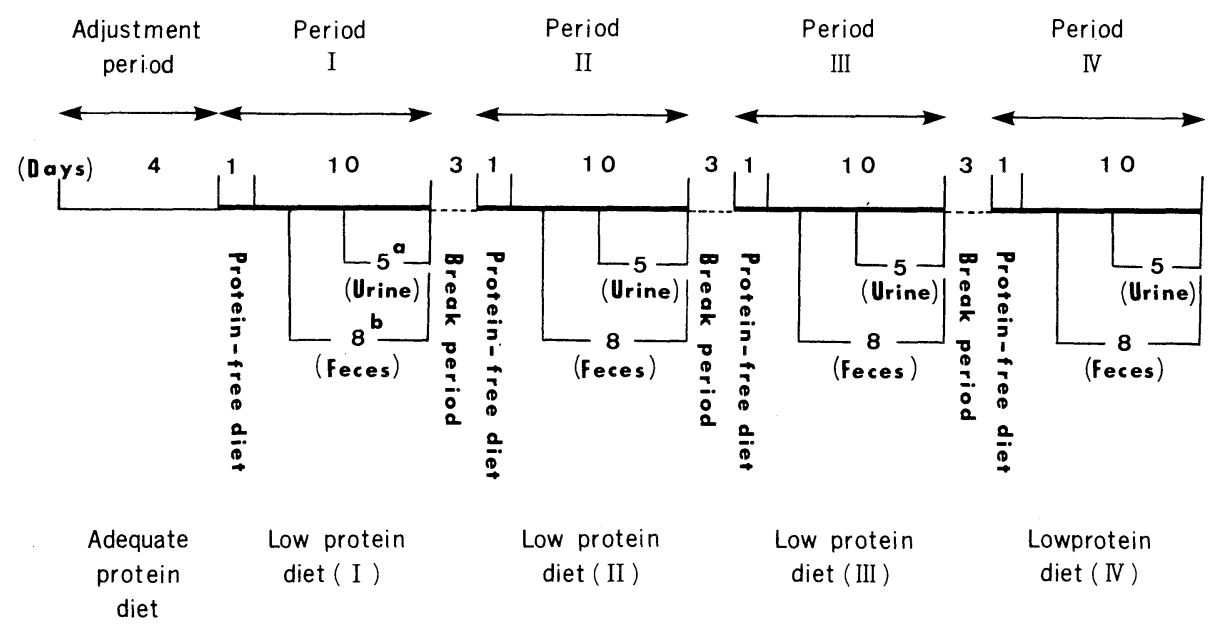

Fig. 1. Experimental design. Subjects were randomly assigned to the four levels of test protein during the four dietary periods. a. The average daily nitrogen excretion in the last five days at each protein level was used in calculating nitrogen balance. $b$. Feces in the last eight days at each protein level were pooled. The average daily fecal nitrogen loss in each period was used in calculating the nitrogen balance and digestibility.

Table 2. Analysis of soy protein isolate. ${ }^{\mathrm{a}}$

\begin{tabular}{lc}
\hline & $\%$ \\
Protein $(\mathrm{N} \times 6.25)$ & 86.5 \\
Moisture & 6.0 \\
Ash & 4.1 \\
Fat & 0.8 \\
Fiber (crude) & 0.25 \\
Calcium & 0.15 \\
Phosphorus & 0.8 \\
Sodium & 1.3 \\
Potassium & 0.05 \\
\hline
\end{tabular}

${ }^{a}$ Supro 620, Ralston Purina Co., St. Louis, Mo., U.S.A.

Square Design to avoid an effect of the previous protein intake on the results. Each period consisted of one day on protein-free diet and ten days on low-protein diet, and was followed by a three-day interval on free-choice (ad libitum) diet (Fig. 1).

The protein sources were soy protein isolate (Supro 620; Ralston Purina Co., St. Louis, Mo., U.S.A.) (Table 2) for five subjects, fish protein (cod fish as a standard) for eight subjects and a mixture of equal amounts of soy protein and fish protein for eight subjects, of whom five (Subjects A, B, C, D and E) also 
Table 3. Compositions of kamaboko products.

\begin{tabular}{lccccc}
\hline & \multicolumn{2}{c}{ SPI $^{\mathrm{a}}$} & & \multicolumn{2}{c}{ Cod } \\
\cline { 2 - 3 } \cline { 5 - 6 } & Parts & $\%$ & & Parts & $\%$ \\
\hline SPI & 20 & 17.5 & & - & - \\
Cod paste & - & - & & 100 & 77.2 \\
NaCl & 3 & 2.6 & & 3 & 2.3 \\
Potato starch & 5 & 4.4 & & 5 & 3.9 \\
Sugar & 1.5 & 1.3 & & 1.5 & 1.2 \\
Water & 85 & 74.2 & & 20 & 15.4 \\
Total & 114.5 & 100.0 & & 129.5 & 100.0 \\
\hline
\end{tabular}

${ }^{\mathrm{a}}$ Soy protein isolate.

Table 4. Diet composition. ${ }^{a}$

\begin{tabular}{ll}
\hline \multicolumn{1}{c}{ Component } & g/day \\
\hline${\text { SPI } \text { kamaboko }^{\mathrm{c}}}^{\mathrm{c}}$ Cod kamaboko $^{\mathrm{c}}$ & 107.5 \\
Sugar $_{\text {Corn starch }}$ & 155 \\
Margarine & 323 \\
Corn oil & 300 \\
Agar & 32 \\
Baking powder & 30 \\
NaCl & 3 \\
Mineral mixture & 5 \\
Vitamin mixture & \\
\end{tabular}

${ }^{\mathrm{a}}$ Intakes are for a $65 \mathrm{~kg}$ subject receiving $0.55 \mathrm{~g} / \mathrm{kg}$ of mixed protein with $45 \mathrm{kcal} / \mathrm{kg}$ of energy. ${ }^{b}$ Soy protein isolate (Supro 620, Ralston Purina Co., St. Louis, Mo.). ${ }^{\mathrm{c}}$ Nitrogen contents are as follows: dried cod, $89.6 \mathrm{mg} / \mathrm{g}$; dried SPI, $147.2 \mathrm{mg} / \mathrm{g}$; cod kamaboko, $18.45 \mathrm{mg} / \mathrm{g}$; SPI kamaboko, $26.6 \mathrm{mg} / \mathrm{g}$. ${ }^{\mathrm{d}}$ For details, see Reference $(13)$.

participated in studies on fish protein and mixed protein. The soy protein isolate and fish protein were prepared as paste products (kamaboko) (Table 3) and diets were given in three equal meals each day. An example of the diet composition is shown in Table 4. The protein levels tested were $0.35,0.45,0.55$ and $0.65 \mathrm{~g}$ protein/ $\mathrm{kg} /$ day $(\mathrm{N} \times 6.25)$ for each protein and these levels were given to each subject in a random order. Energy intakes were constant for each individual and were sufficient to maintain his body weight (mean $\pm \mathrm{SD}=44.6 \pm 2.4 \mathrm{kcal} / \mathrm{kg} /$ day ranging from 38.4 to $49.8 \mathrm{kcal} / \mathrm{kg} /$ day).

All urine was collected and the average nitrogen excretion in the last five days 
at each protein level was used for calculating the nitrogen balance. Feces in the last eight days of each test period were pooled. True digestibility was calculated at each level of protein intake using the value of $12.4 \mathrm{mg} \mathrm{N} / \mathrm{kg}$ for metabolic fecal nitrogen (3). The nitrogen balance response to nitrogen intake was observed for each individual and the regression equation relating nitrogen balance to nitrogen intake was calculated from pooled data together with the $97.5 \%$ confidence intervals. The minimum nitrogen requirement was estimated from the regression line. Net protein utilization (NPU) at nitrogen equilibrium was also calculated. The nutritional value of soy protein isolate was estimated from the slope of the nitrogen balance response curve and compared with that for fish protein.

Body weight was measured daily at 7:00 a.m. with minimal clothing after voiding urine and before breakfast. Total nitrogen, creatinine (4), urea (5), ammonia (5), uric acid (6), sodium and potassium in urine samples were measured. Blood was drawn from an antecubital vein at 6:30 a.m. after an overnight fast of about $10 \mathrm{hr}$ on the last days of the adjustment period and of each period on low protein diet. Routine hematological analyses (erythrocyte and leucocyte counts, hemoglobin and hematocrit) were carried out, and total protein (7), albumin (8), urea (5), SGOT (9), SGPT (9), glucose (10), triglyceride (11), total cholesterol (12), sodium and potassium in plasma were also measured. Anthropometric measurements to detect possible physical changes, such as measurements of the circumference of the chest, waist and mid-upper arm and skin-fold thicknesses of the subscapular, suprailiac, triceps and biceps areas were conducted at the ends of the adjustment period and each period on low protein diet.

\section{RESULTS}

Date on nitrogen balance with the three proteins are summarized in Table 5 . Fecal nitrogen did not increase appreciably with increase in soy protein or fish protein intake and therefore the two proteins were almost completely digested. Nitrogen balance for soy protein was significantly lower than that for fish protein $(p<0.05)$ at the same protein intakes of $0.45,0.55$ and $0.65 \mathrm{~g}$ protein $/ \mathrm{kg} / \mathrm{day}$. There were no significant differences between the nitrogen balances of fish protein and mixed protein at any level of nitrogen intake tested.

Individual nitrogen balance data were plotted against nitrogen intake in Figs. 2, 3 and 4. From these results, regression equations relating nitrogen balance to nitrogen intake for individual subjects were calculated and are given in Table 6 . Nitrogen balance in subject $\mathrm{K}$ given fish protein was inversely related to nitrogen intake and so these data were omitted from further analyses. The slopes of regression lines showed wide individual ranges of $0.210-0.396$ for soy protein, $0.158-0.461$ for fish protein and $0.171-0.620$ for mixed protein. The regression lines obtained from pooled nitrogen balance data are shown in Fig. 5. The slope for soy protein $(0.298)$ was smaller than those for fish protein $(0.365)$ and mixed protein (0.423), but the differences were not statistically significant. 


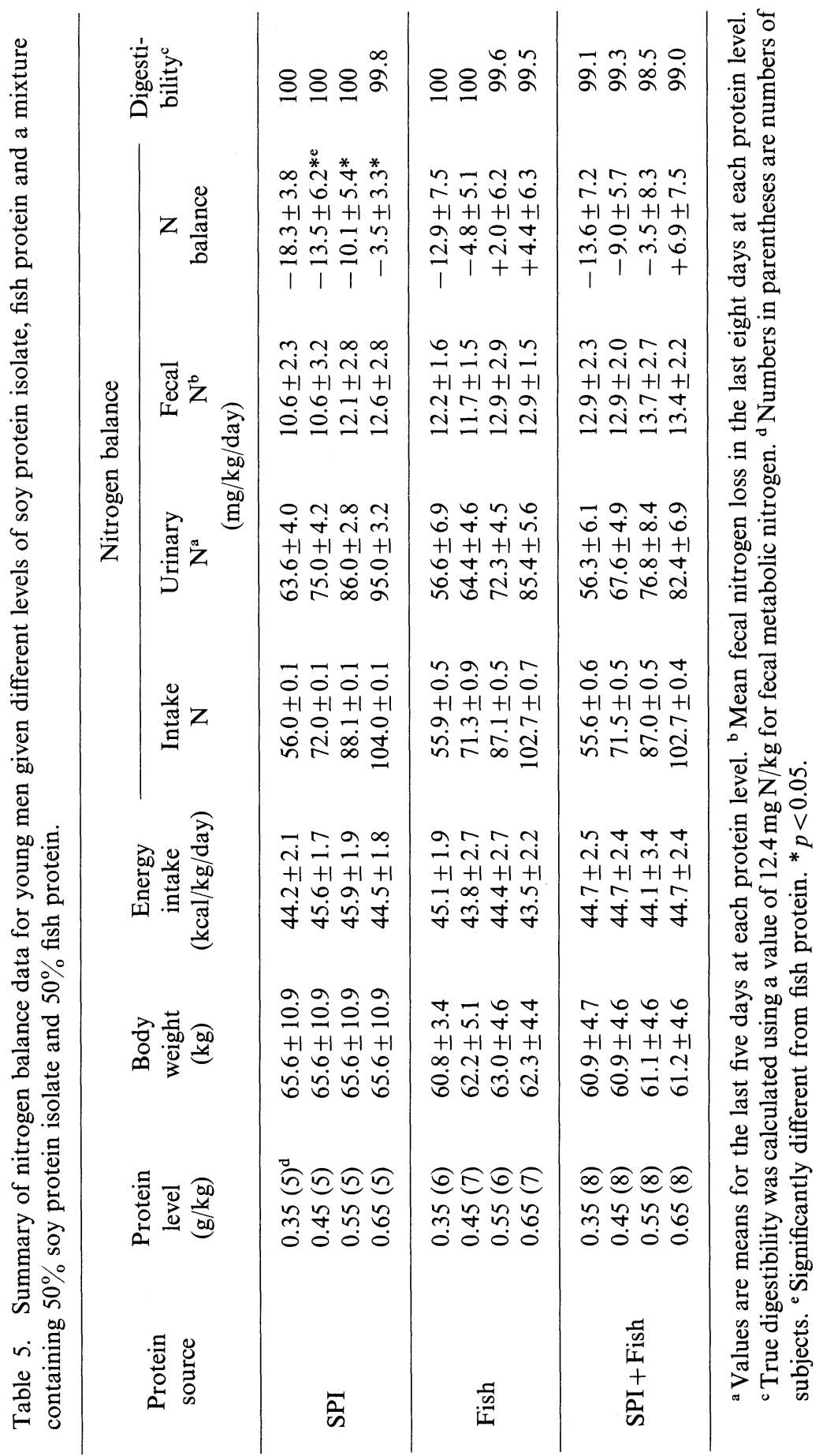




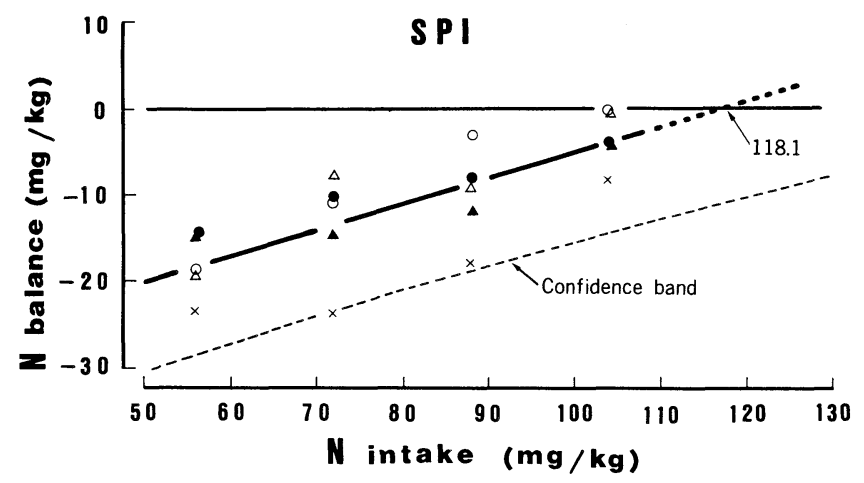

Fig. 2. Relationship between nitrogen intake and nitrogen balance of individual subjects fed soy protein isolate. Subj. M (O), Subj. N (•), Subj. O (×), Subj. P $(\triangle)$, Subj. Q ( $\mathbf{\Delta})$.

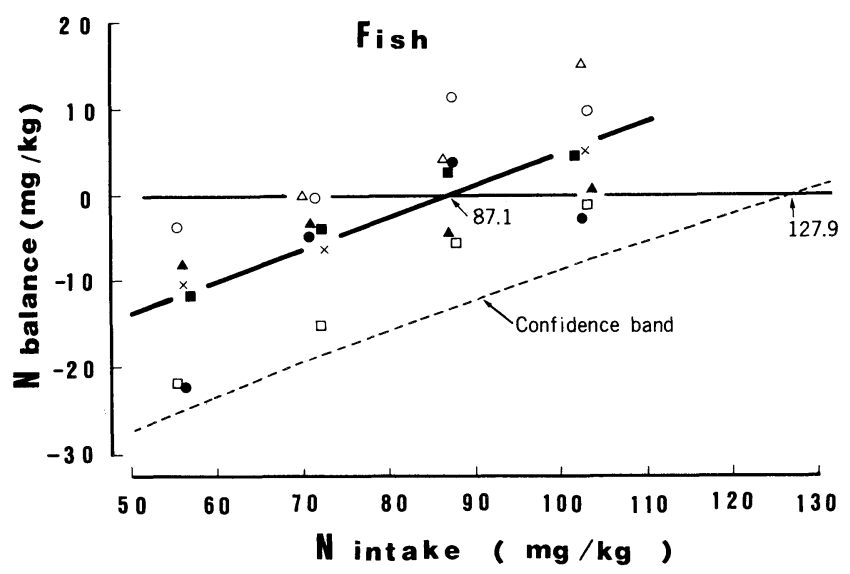

Fig. 3. Relationship between nitrogen intake and nitrogen balance of individual subjects fed fish protein. Subj. A (O), Subj. B (๑), Subj. C (×), Subj. D ( $\triangle)$, Subj. E (A), Subj. F ( $\square$ ), Subj. G (ם).

The mean nitrogen intake for apparent nitrogen equilibrium (intercept of the lines for nitrogen intake with nitrogen equilibrium) determined from individual regression lines was $120.5 \mathrm{mg} \mathrm{N} / \mathrm{kg}$ (range 101-138) for soy protein, which was significantly higher than $87.7 \mathrm{mg} \mathrm{N} / \mathrm{kg}$ (range 66-104) for fish protein (Table 6). There was no significant difference between the maintenance nitrogen intakes of fish protein and mixed protein. The coefficient of variation of the maintenance nitrogen intake was $13.3 \%$ for soy protein, $16.5 \%$ for fish protein and $22.9 \%$ for mixed protein. The maintenance nitrogen levels obtained from pooled data, that is, 118.1 $\mathrm{mg} \mathrm{N} / \mathrm{kg}$ for soy protein, $87.1 \mathrm{mg} \mathrm{N} / \mathrm{kg}$ for fish protein and $90.5 \mathrm{mg} \mathrm{N} / \mathrm{kg}$ for mixed protein, were similar to those obtained from individual data (Table 6). The protein 


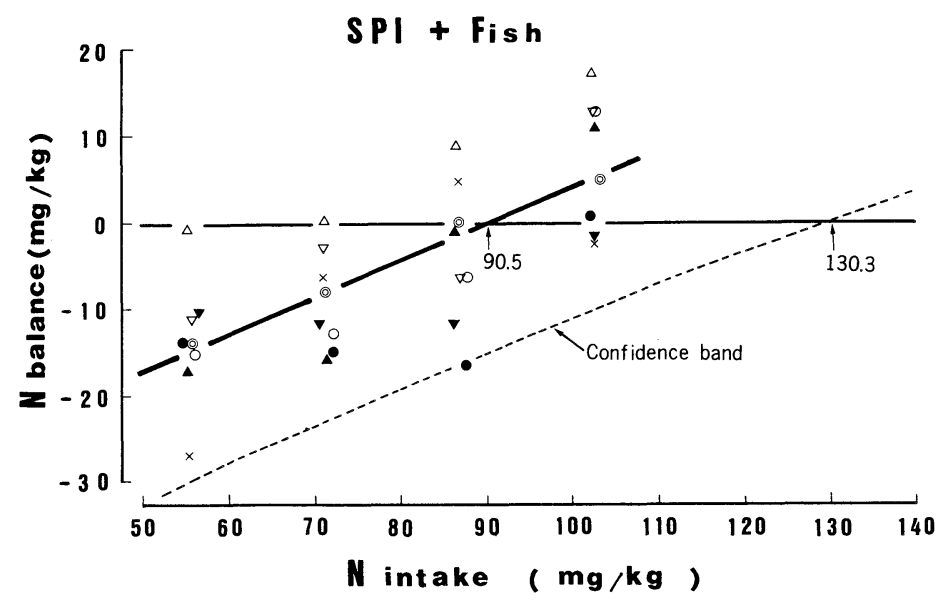

Fig. 4. Relationship between nitrogen intake and nitrogen balance of individual subjects fed a mixture of $50 \%$ SPI and $50 \%$ fish protein. Subj. A (O), Subj. B (O), Subj. C $(\times)$, Subj. D $(\triangle)$, Subj. E $(\Delta)$, Subj. H (O), Subj. I $(\nabla)$, Subj. J $(\nabla)$.

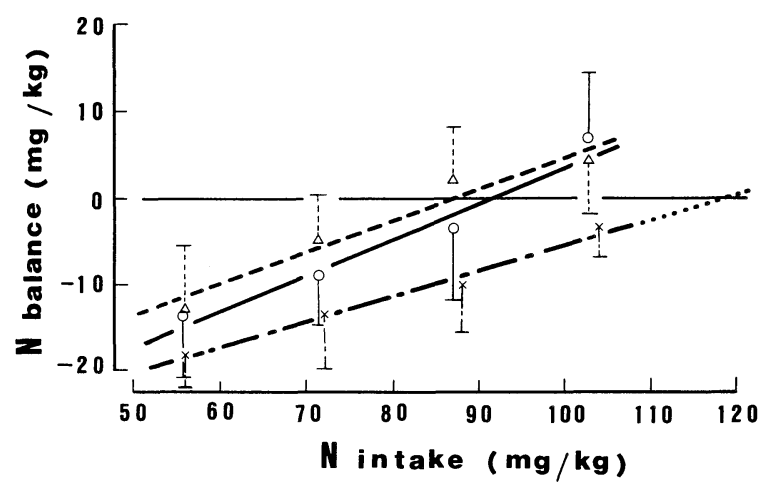

Fig. 5. Regression lines for soy protein isolate, fish protein, and a mixture of soy protein and fish protein.

$$
\begin{array}{cc}
\times--\times, \text { soy protein isolate } & Y=0.298 X-35.2(n=20) \\
& \text { Maintenance }=118.1 \pm 15.4 \mathrm{mg} \mathrm{N} / \mathrm{kg} / \text { day } \\
\triangle & Y=0.365 X-31.8(n=26) \\
& \text { Maintenance }=87.1 \pm 17.2 \mathrm{mg} \mathrm{N} / \mathrm{kg} / \text { day } \\
\bigcirc-\triangle, \text { fish protein } \quad 50 \% \text { soy protein isolate }+50 \% \text { fish protein } \\
Y=0.423 X-38.3(n=32) \\
\text { Maintenance }=90.5 \pm 17.1 \mathrm{mg} \mathrm{N} / \mathrm{kg} / \text { day }
\end{array}
$$

allowance, estimated from the intersection of the upper $97.5 \%$ confidence band with the zero balance line, was $166 \mathrm{mg} \mathrm{N} / \mathrm{kg}$ for soy protein, $128 \mathrm{mg} \mathrm{N} / \mathrm{kg}$ for fish protein and $130 \mathrm{mg} \mathrm{N} / \mathrm{kg}$ for mixed protein (Figs. 2, 3 and 4).

NPUs calculated at the respective maintenance nitrogen levels from individual 


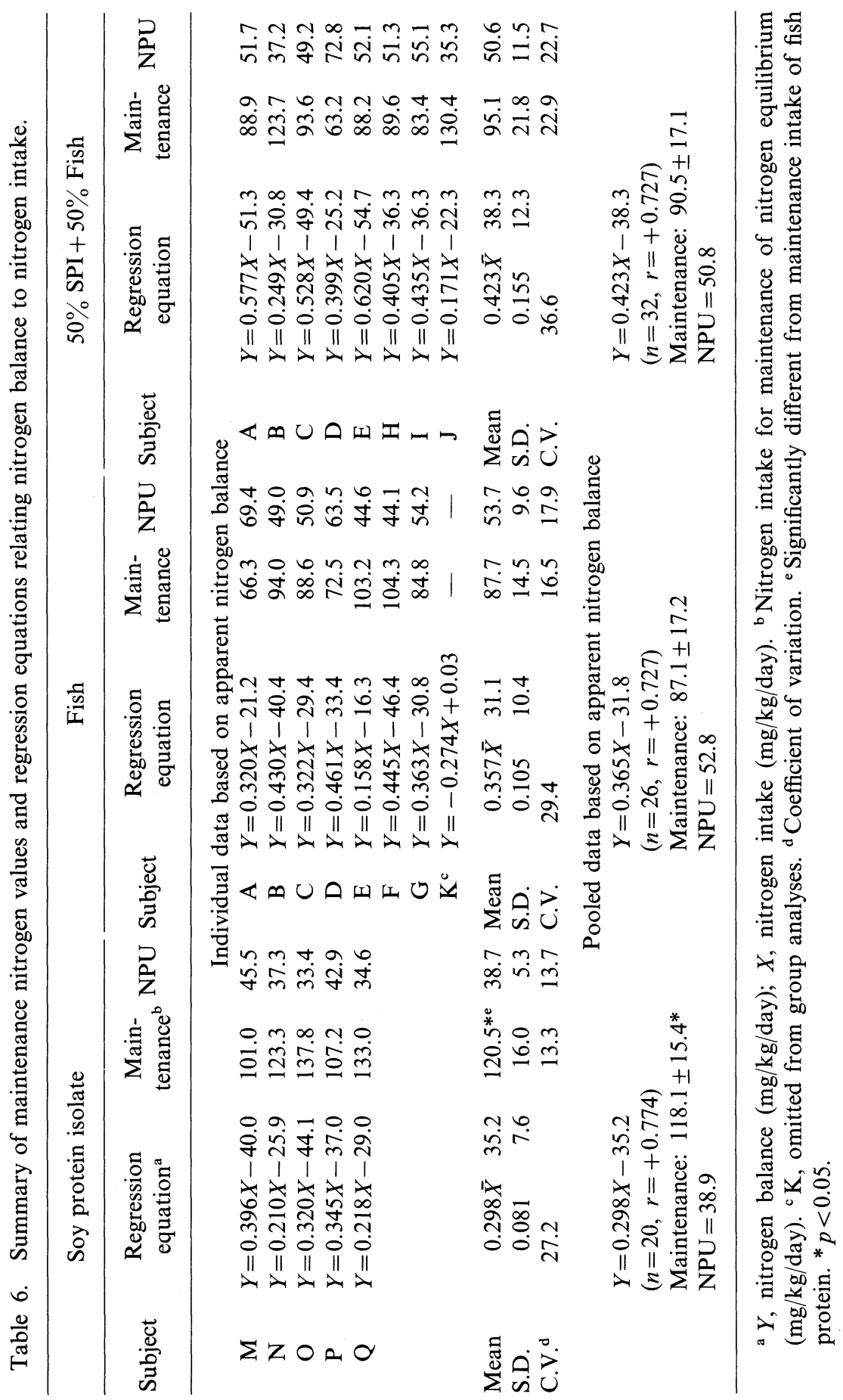


data were $38.7 \pm 5.3$ for soy protein, $53.7 \pm 9.6$ for fish protein and $50.6 \pm 11.5$ for mixed protein (Table 6). The NPUs obtained from pooled data were similar to those obtained from individual data. Values for the protein quality of soy protein isolate relative to fish protein estimated from pooled data were $82 \%(0.298 \mathrm{mg} \mathrm{N} / \mathrm{kg}$ vs $0.365 \mathrm{mg} \mathrm{N} / \mathrm{kg}$ ), $74 \%$ (118.1 vs 87.1) and $74 \%$ (38.9 vs 52.8) based on the regression coefficients ("slope ratios"), nitrogen requirements ("maintenance intakes") and NPU, respectively.

Values determined in anthropometric, blood and urine analyses were not significantly affected by differences in the dietary protein source (Appendices 1, 2, 3, 4 and 5).

\section{DISCUSSION}

In this study we examined the nutritional quality of well processed soy protein product by giving it to young men at four protein levels within the submaintenanceto-maintenance range and evaluated the nutritive value of soy protein isolate relative to fish protein by various methods based on nitrogen balance data. The digestibilities of soy protein isolate and fish protein were both very high, being about $100 \%$, which is comparable with that of egg protein (13). Since the digestibility of cooked soybean was reported to be $92 \%(14)$, isolation of soy protein improved its digestibility. The slope of the regression line relating nitrogen balance to nitrogen intake was 0.298 for pooled data on soy protein as compared with 0.365 for those on fish protein. The slope for soy protein was less than that for egg protein (0.411) estimated previously(13). Using the slope ratio method, the relative nutritive value of soy protein was estimated to be $82 \%$ and $73 \%$ of the values of fish and egg proteins, respectively. However, the NPU of soy protein at maintenance nitrogen intake, that is 38.9 , corresponded to $74 \%$ of that for fish protein (NPU = 52.8 ) and $76 \%$ of that for egg protein (NPU $=51.1$ ). Young et al. (15) evaluated the protein quality of soy protein as $87 \%$ and $77 \%$ of that of egg protein from the slope of the regression line based on pooled and individual data, respectively. Thus the quality of the soy protein isolate used in this study roughly corresponded to $80 \%$ of that of fish protein and egg protein.

The maintenance nitrogen requirement for apparent nitrogen equilibrium obtained from the regression equation of pooled data was $118 \pm 15 \mathrm{mg} \mathrm{N} / \mathrm{kg} /$ day for soy protein isolate and $87.1 \pm 17.2 \mathrm{mg} \mathrm{N} / \mathrm{kg} /$ day for fish protein. There was no significant difference between the requirement of fish protein determined in this study and that of egg protein $(90.1 \pm 14.1 \mathrm{mg} \mathrm{N} / \mathrm{kg} /$ day) reported previously (13), but the soy protein requirement was higher than that of egg protein. From these figures, the relative nitrogen requirement of soy protein isolate was calculated as $74 \%$ and $76 \%$ of the requirements of fish and egg proteins, respectively. Vemury et al. (16) observed a lower nitrogen balance with soy protein concentrate than with egg and beef at nitrogen intakes of $4.0 \mathrm{~g} \mathrm{~N} /$ day of test proteins. Kies and Fox (17) found on the basis of nitrogen balance data that although the nutritional value of 
textured soy protein was inferior to that of beef at $4 \mathrm{~g}$ nitrogen intake, those of the two proteins were similar at $8 \mathrm{~g}$ nitrogen intake per day. Zezulka and Calloway (18) reported that the average nitrogen balances obtained with soy protein isolate were $-1.21,-0.08,+0.26$ and $+0.79 \mathrm{~g}$ nitrogen per day at $3.0,4.5,6.0$ and $7.5 \mathrm{~g}$ soy nitrogen intake per day, respectively, with a total nitrogen intake of $9 \mathrm{~g} /$ day adjusted by adding non-specific nitrogen in the form of a mixture of glycine and alanine in isonitrogenous amounts. The maintenance nitrogen intake obtained from their nitrogen balance data is considerably lower than that obtained in this study, possibly because of the difference in the total nitrogen intake. Young et al.(15) observed a similar value to ours for maintenance nitrogen intake of soy protein isolate (judging by inspection of their figure for nitrogen balance (15); Fig. 5, p. 114). They also calculated the relative nitrogen requirement of soy protein isolate as $80 \%$ of the egg protein requirement, which is similar to our value of about $75 \%$ described above.

The lower quality of soy protein relative to fish or egg protein may be due to its lower content of sulfur amino acids. Kies and Fox(17) and Zezulka and Calloway(18) observed an improvement of the nitrogen balance by adding methionine to soy protein at low nitrogen intake. Young et al. (15) observed a similar effect when $0.6 \%$ or $1.1 \%$ methionine was added to soy protein at $0.51 \mathrm{~g}$ protein $/ \mathrm{kg} /$ day. But they observed a negative effect when $1.6 \%$ methionine was added to $0.51 \mathrm{~g}$ soy protein $/ \mathrm{kg} /$ day, although a positive effect of $1.6 \%$ methionine was still observed at $0.8 \mathrm{~g}$ soy protein $/ \mathrm{kg} / \mathrm{day}$. In the present study, we examined nitrogen utilization with soy-fish combination instead of methionine supplementation. Soy protein in combination with an isonitrogenous amount of fish protein had essentially the same nutritive value as fish protein alone judging from data on nitrogen balance, the slope of the regression line, the maintenance nitrogen intake and the NPU. Kies and Fox (17) and Young et al.(15) investigated the protein quality of combinations of soy and beef in ratios of $4: 0,3: 1,2: 2,1: 3$ and $0: 4$. Kies and Fox (17) obtained a linear increase in nitrogen balance with increase in the ratio of beef to soy at $4.8 \mathrm{~g}$ nitrogen per day per person, but Young et al. (15) observed no differences in the nitrogen balance with the same combinations of beef and soy protein at $0.6 \mathrm{~g}$ protein $/ \mathrm{kg}$ body weight $/$ day. Thus, the nutritional quality of soy protein may depend on the level of protein intake as well as the individual soy protein product.

It is concluded from the present study and the above discussion that soy protein isolate has a nutritive value of about $80 \%$ of that of fish or egg protein and is a good source of protein for human consumption. However, long-term studies like those of Young et al. (15) should be carried out on a wide variety of subjects to detect possible adverse effects of this protein source.

Some blood analyses and anthropometric measurements were carried out by Prof. K. Oikawa and Prof. K. Fujiwara, School of Medicine, The University of Tsukuba. Paste products (kamaboko) of Supro 620 and cod fish were supplied by Ralston Purina Co., St. 
Louis, Mo., U.S.A. and Fuji Oil Co., Osaka, Japan. This work was supported in part by a grant (No. 357049) from the Ministry of Education, Science and Culture of Japan.

\section{REFERENCES}

1) Proceedings of "World Conference on Vegetable Food Proteins." J. Am. Oil Chem. Soc., 56, 99-483, 1979.

2) Carroll, K. K., Huff, M. W., and Roberts, D. C. K. (1979): Vegetable protein and lipid metabolism, in Soy Protein and Human Nutrition, ed. Wilcke, H. L., Hopkins, D. T., and Waggle, D. H., Academic Press, New York, pp. 261-280.

3) Inoue, G., Fujita, Y., Kishi, K., Yamamoto, S., and Niiyama, Y. (1974): Nutritive values of egg protein and wheat gluten in young men. Nutr. Rep. Int., 10, 201-207.

4) Koishi, H. (1962): A critical examination on the Folin's method for determination of creatinine concentration in the urine. Osaka City Med. J., 8, 1-15.

5) Searcy, R. L., and Cox, F. M. (1963): A modified technique for ultramicro estimations of urea nitrogen. Clin. Chim. Acta, 20, 1553-1555.

6) Henry, R. J., Sobel, C., and Kim, J. (1957): A modified carbonate-phosphotungstate method for the determination of uric acid and comparison with the spectrophotometric uricase method. Am. J. Clin. Pathol., 28, 152-160.

7) Gornall, A. G., Bardawill, C. J., and David, M. M. (1949): Determination of serum proteins by means of the biuret reaction. J. Biol. Chem., 177, 751-766.

8) Martinek, R. G. (1965): Evaluation of a dye-binding method for determination of serum albumin. Clin. Chem., 11, 441-447.

9) Reitman, S., and Frankel, S. (1957): A colorimetric method for the determination of serum glutamic oxaloacetic and glutamic pyruvic transaminases. Am. J. Clin. Pathol., 28, 56-63.

10) Somogyi, M. (1952): Notes on sugar determination. J. Biol. Chem., 195, 19-23.

11) Van Hendel, E., and Zilversmit, D. B. (1957): Micromethod for the direct determination of serum triglycerides. J. Lab. Clin. Med., 50, 152-157.

12) Zak, B. (1957): Simple rapid microtechnic for serum total cholesterol. Am. J. Clin. Pathol., 27, 583-588.

13) Inoue, G., Fujita, Y., and Niiyama, Y. (1973): Studies on protein requirements of young men fed egg protein and rice protein with excess and maintenance energy intakes. J. Nutr., 103, 1673-1687.

14) National Institute of Resources. (1979): Investigation on Metabolizable Energy of Soybean and Its Products in Japanese. Science and Technology Agency, Tokyo.

15) Young, V. R., Scrimshaw, N. S., Torun, B., and Viteri, F. (1979): Soybean protein in human nutrition: An overview. J. Am. Oil Chem. Soc., 56, 110-120.

16) Vemury, M. K. D., Kies, C., and Fox, H. M. (1976): Comparative protein value of several vegetable protein products fed at equal nitrogen levels to human adults. J. Food Sci., 41, 1086-1091.

17) Kies, C., and Fox, H. M. (1971): Comparison of the protein nutritional value of TVP, methionine enriched TVP and beef at two levels of intakes for human adults. J. Food Sci., 36, 841-845.

18) Zezulka, A. Y., and Calloway, D. H. (1976): Nitrogen retention in men fed varying levels of amino acids from soy protein with or without added L-methionine. J. Nutr., 106, 212-221. 
Appendix 1. Basal metabolism and anthropometric data.

\begin{tabular}{|c|c|c|c|c|c|c|c|}
\hline & \multirow{2}{*}{\multicolumn{2}{|c|}{$\begin{array}{l}\text { Protein } \\
\text { source }\end{array}$}} & \multirow{2}{*}{ Control } & \multicolumn{4}{|c|}{ Protein level $(\mathrm{g} / \mathrm{kg})$} \\
\hline & & & & 0.35 & 0.45 & 0.55 & 0.65 \\
\hline \multirow{3}{*}{$\begin{array}{l}\text { Basal } \\
\text { metabolism } \\
(\mathrm{kcal} / \mathrm{kg})\end{array}$} & SPI & $(5)$ & $24.2 \pm 0.8$ & - & - & - & - \\
\hline & Fish & (8) & $24.0 \pm 2.1$ & $23.4 \pm 1.5$ & $23.1 \pm 2.0$ & $22.7 \pm 2.3$ & $22.9 \pm 1.4$ \\
\hline & Mix. & $(8)$ & $24.4 \pm 2.0$ & $22.7 \pm 0.9$ & $23.9 \pm 1.2$ & $24.1 \pm 1.2$ & $23.4 \pm 1.0$ \\
\hline \multirow{3}{*}{$\begin{array}{l}\text { Chest } \\
\text { circum. } \\
(\mathrm{cm})\end{array}$} & SPI & $(5)$ & $92.3 \pm 4.7$ & $91.4 \pm 4.2$ & $91.9 \pm 3.8$ & $92.1 \pm 4.9$ & $92.0 \pm 5.2$ \\
\hline & Fish & $(8)$ & $88.6 \pm 4.8$ & $88.2 \pm 4.5$ & $88.3 \pm 4.7$ & $88.8 \pm 4.3$ & $88.7 \pm 4.7$ \\
\hline & Mix. & $(8)$ & $87.6 \pm 4.6$ & $87.2 \pm 3.9$ & $87.8 \pm 4.2$ & $87.3 \pm 4.9$ & $87.0 \pm 4.9$ \\
\hline \multirow{3}{*}{$\begin{array}{l}\text { Waist } \\
\text { circum. } \\
(\mathrm{cm})\end{array}$} & SPI & $(5)$ & $75.3 \pm 6.0$ & $75.1 \pm 4.9$ & $75.3 \pm 5.2$ & $75.2 \pm 5.1$ & $75.9 \pm 5.6$ \\
\hline & Fish & (8) & $72.8 \pm 6.2$ & $72.8 \pm 5.9$ & $72.7 \pm 5.6$ & $72.4 \pm 5.3$ & $73.0 \pm 5.2$ \\
\hline & Mix. & $(8)$ & $71.7 \pm 4.1$ & $72.1 \pm 4.9$ & $72.8 \pm 4.6$ & $71.6 \pm 4.4$ & $71.4 \pm 3.9$ \\
\hline \multirow{3}{*}{$\begin{array}{l}\text { Mid-upper } \\
\text { arm circum. } \\
(\mathrm{cm})\end{array}$} & SPI & & - & - & - & - & - \\
\hline & Fish & (8) & $26.0 \pm 1.4$ & $25.9 \pm 1.5$ & $25.8 \pm 1.5$ & $25.6 \pm 1.3$ & $25.7 \pm 1.4$ \\
\hline & Mix. & (8) & $26.0 \pm 1.1$ & $25.5 \pm 1.1$ & $25.5 \pm 1.1$ & $25.7 \pm 1.3$ & $25.6 \pm 1.3$ \\
\hline \multicolumn{8}{|l|}{ Skin fold (mm) } \\
\hline \multirow{3}{*}{ Subscapular } & SPI & $(5)$ & $9.6 \pm 3.2$ & $10.2 \pm 3.3$ & $10.4 \pm 3.8$ & $10.1 \pm 3.2$ & $10.3 \pm 3.0$ \\
\hline & Fish & (8) & $11.9 \pm 3.8$ & $12.7 \pm 4.4$ & $13.0 \pm 4.3$ & $12.2 \pm 3.0$ & $12.4 \pm 4.1$ \\
\hline & Mix. & $(8)$ & $9.9 \pm 3.5$ & $9.3 \pm 2.9$ & $9.5 \pm 3.3$ & $9.6 \pm 3.5$ & $9.2 \pm 3.0$ \\
\hline \multirow{3}{*}{ Suprailiac } & SPI & & - & - & - & - & - \\
\hline & Fish & (8) & $18.9 \pm 7.2$ & $19.4 \pm 8.0$ & $20.0 \pm 8.5$ & $20.5 \pm 7.8$ & $19.7 \pm 8.4$ \\
\hline & Mix. & (8) & $14.1 \pm 4.3$ & $14.3 \pm 5.3$ & $14.3 \pm 5.6$ & $14.6 \pm 5.4$ & $14.0 \pm 5.2$ \\
\hline \multirow{3}{*}{ Triceps } & SPI & (5) & $7.7 \pm 1.2$ & $6.8 \pm 1.3$ & $7.5 \pm 1.3$ & $7.1 \pm 1.6$ & $7.7 \pm 1.7$ \\
\hline & Fish & (8) & $9.1 \pm 3.7$ & $9.4 \pm 4.8$ & $9.2 \pm 4.2$ & $9.6 \pm 3.4$ & $9.2 \pm 2.6$ \\
\hline & Mix. & (8) & $7.7 \pm 2.7$ & $7.2 \pm 2.3$ & $7.4 \pm 2.3$ & $7.4 \pm 2.6$ & $7.1 \pm 1.6$ \\
\hline \multirow{3}{*}{ Biceps } & SPI & & - & - & - & - & - \\
\hline & Fish & (8) & $4.9 \pm 1.8$ & $5.3 \pm 2.2$ & $5.0 \pm 1.9$ & $4.8 \pm 2.0$ & $4.9 \pm 1.9$ \\
\hline & Mix. & (8) & $4.1 \pm 1.7$ & $3.6 \pm 1.3$ & $3.6 \pm 1.5$ & $4.2 \pm 1.7$ & $4.0 \pm 1.4$ \\
\hline
\end{tabular}


Appendix 2. Blood analysis (1).

\begin{tabular}{|c|c|c|c|c|c|c|c|}
\hline & \multirow{2}{*}{\multicolumn{2}{|c|}{$\begin{array}{l}\text { Protein } \\
\text { source }\end{array}$}} & \multirow{2}{*}{ Control } & \multicolumn{4}{|c|}{ Protein level $(\mathrm{g} / \mathrm{kg})$} \\
\hline & & & & 0.35 & 0.45 & 0.55 & 0.65 \\
\hline \multirow{3}{*}{$\begin{array}{l}\text { RBC counts } \\
\left(\times 10^{4} / \mathrm{mm}^{3}\right)\end{array}$} & SPI & $(5)$ & $505 \pm 18$ & $492 \pm 24$ & $488 \pm 25$ & $483 \pm 10$ & $491 \pm 42$ \\
\hline & Fish & (7) & $438 \pm 18$ & $438 \pm 15$ & $435 \pm 16$ & $428 \pm 17$ & $437 \pm 17$ \\
\hline & Mix. & (8) & $441 \pm 23$ & $429 \pm 23$ & $423 \pm 21$ & $426 \pm 17$ & $424 \pm 23$ \\
\hline \multirow{3}{*}{$\begin{array}{l}\text { WBC counts } \\
\left(\times 10^{3} / \mathrm{mm}^{3}\right)\end{array}$} & SPI & (5) & $6.90 \pm 2.10$ & $6.20 \pm 2.80$ & $5.70 \pm 1.30$ & $5.90 \pm 2.00$ & $5.80 \pm 1.80$ \\
\hline & Fish & (7) & $5.65 \pm 1.30$ & $5.16 \pm 1.13$ & $4.82 \pm 1.13$ & $4.83 \pm 0.83$ & $4.77 \pm 1.24$ \\
\hline & Mix. & (8) & $5.18 \pm 1.03$ & $4.95 \pm 0.85$ & $5.09 \pm 0.98$ & $5.47 \pm 0.99$ & $5.45 \pm 0.94$ \\
\hline \multirow{3}{*}{$\begin{array}{l}\text { Hemoglobin } \\
(\mathrm{g} / 100 \mathrm{ml})\end{array}$} & SPI & $(5)$ & $15.4 \pm 0.8$ & $15.2 \pm 0.7$ & $14.8 \pm 0.8$ & $14.7 \pm 0.7$ & $14.9 \pm 1.1$ \\
\hline & Fish & (7) & $16.1 \pm 0.5$ & $16.0 \pm 0.5$ & $15.8 \pm 0.5$ & $15.5 \pm 0.8$ & $15.7 \pm 0.3$ \\
\hline & Mix. & (8) & $16.3 \pm 1.3$ & $15.7 \pm 0.7$ & $15.4 \pm 0.6$ & $15.7 \pm 0.8$ & $15.6 \pm 0.5$ \\
\hline \multirow{3}{*}{ Hematocrit } & SPI & (5) & $44.8 \pm 1.5$ & $43.5 \pm 2.4$ & $42.5 \pm 2.6$ & $42.4 \pm 2.3$ & $43.0 \pm 3.4$ \\
\hline & Fish & (7) & $45.8 \pm 1.7$ & $45.7 \pm 1.6$ & $45.0 \pm 1.3$ & $44.6 \pm 2.3$ & $45.0 \pm 1.2$ \\
\hline & Mix. & (8) & $45.7 \pm 3.0$ & $44.5 \pm 1.5$ & $43.7 \pm 1.4$ & $44.3 \pm 2.1$ & $43.9 \pm 1.4$ \\
\hline
\end{tabular}

Appendix 3. Blood analysis (2).

\begin{tabular}{|c|c|c|c|c|c|c|c|}
\hline & \multirow{2}{*}{\multicolumn{2}{|c|}{$\begin{array}{l}\text { Protein } \\
\text { source }\end{array}$}} & \multirow{2}{*}{ Control } & \multicolumn{4}{|c|}{ Protein level $(\mathrm{g} / \mathrm{kg})$} \\
\hline & & & & 0.35 & 0.45 & 0.55 & 0.65 \\
\hline \multirow{3}{*}{$\begin{array}{l}\text { Total } \\
\text { protein } \\
(\mathrm{g} / 100 \mathrm{ml})\end{array}$} & SPI & (5) & $7.70 \pm 0.30$ & $7.80 \pm 0.30$ & $7.70 \pm 0.40$ & $7.80 \pm 0.30$ & $7.80 \pm 0.50$ \\
\hline & Fish & (7) & $7.10 \pm 0.56$ & $6.90 \pm 0.45$ & $6.79 \pm 0.36$ & $6.54 \pm 0.23$ & $6.76 \pm 0.47$ \\
\hline & Mix. & (8) & $7.05 \pm 0.42$ & $6.55 \pm 0.31$ & $6.48 \pm 0.38$ & $6.49 \pm 0.32$ & $6.50 \pm 0.38$ \\
\hline \multirow{3}{*}{$\begin{array}{l}\text { Albumin } \\
(\mathrm{g} / 100 \mathrm{ml})\end{array}$} & SPI & (5) & $4.80 \pm 0.20$ & $4.80 \pm 0.20$ & $4.70 \pm 0.20$ & $4.80 \pm 0.20$ & $4.80 \pm 0.30$ \\
\hline & Fish & (7) & $4.28 \pm 0.28$ & $4.34 \pm 0.25$ & $4.21 \pm 0.28$ & $4.16 \pm 0.42$ & $4.27 \pm 0.36$ \\
\hline & Mix. & (8) & $4.47 \pm 0.39$ & $4.27 \pm 0.32$ & $4.25 \pm 0.22$ & $4.21 \pm 0.23$ & $4.26 \pm 0.17$ \\
\hline \multirow{3}{*}{$\begin{array}{l}\text { Urea-N } \\
(\mathrm{mg} / 100 \mathrm{ml})\end{array}$} & SPI & (5) & $17.5 \pm 5.5$ & $12.6 \pm 3.8$ & $12.8 \pm 5.3$ & $12.8 \pm 4.0$ & $14.3 \pm 4.2$ \\
\hline & Fish & (7) & $10.4 \pm 2.0$ & $4.6 \pm 1.6$ & $4.8 \pm 2.5$ & $4.7 \pm 2.0$ & $7.0 \pm 3.4$ \\
\hline & Mix. & (8) & $10.2 \pm 2.2$ & $3.7 \pm 1.8$ & $4.3 \pm 1.4$ & $4.9 \pm 2.2$ & $5.3 \pm 1.3$ \\
\hline \multirow{3}{*}{$\begin{array}{l}\text { GOT } \\
\text { (Karmen U.) }\end{array}$} & SPI & (5) & $15 \pm 4$ & $14 \pm 3$ & $14 \pm 3$ & $13 \pm 3$ & $14 \pm 4$ \\
\hline & Fish & (7) & $16 \pm 5$ & $11 \pm 5$ & $13 \pm 9$ & $12 \pm 2$ & $13 \pm 5$ \\
\hline & Mix. & (8) & $15 \pm 4$ & $13 \pm 9$ & $14 \pm 8$ & $12 \pm 6$ & $12 \pm 6$ \\
\hline \multirow{3}{*}{$\begin{array}{l}\text { GPT } \\
\text { (Karmen U.) }\end{array}$} & SPI & (5) & $11 \pm 4$ & $10 \pm 3$ & $12 \pm 2$ & $10 \pm 3$ & $11 \pm 4$ \\
\hline & Fish & (7) & $8 \pm 6$ & $8 \pm 7$ & $9 \pm 9$ & $6 \pm 4$ & $8 \pm 6$ \\
\hline & Mix. & (8) & $9 \pm 4$ & $7 \pm 9$ & $7 \pm 6$ & $8 \pm 9$ & $8 \pm 10$ \\
\hline
\end{tabular}


Appendix 4. Blood analysis (3).

\begin{tabular}{|c|c|c|c|c|c|c|c|}
\hline & \multirow{2}{*}{\multicolumn{2}{|c|}{$\begin{array}{l}\text { Protein } \\
\text { source }\end{array}$}} & \multirow{2}{*}{ Control } & \multicolumn{4}{|c|}{ Protein level $(\mathrm{g} / \mathrm{kg})$} \\
\hline & & & & 0.35 & 0.45 & 0.55 & 0.65 \\
\hline \multirow{3}{*}{$\begin{array}{l}\text { Glucose } \\
\text { (mg/100 ml) }\end{array}$} & SPI & (5) & - & - & - & - & - \\
\hline & Fish & (7) & $84.4 \pm 5.9$ & $94.4 \pm 9.4$ & $88.5 \pm 6.4$ & $87.8 \pm 7.8$ & $88.1 \pm 10.5$ \\
\hline & Mix. & (8) & $77.8 \pm 5.9$ & $87.1 \pm 5.4$ & $86.9 \pm 8.3$ & $85.5 \pm 6.1$ & $85.0 \pm 5.1$ \\
\hline \multirow{3}{*}{$\begin{array}{l}\text { Triglyceride } \\
\text { (mg/100 ml) }\end{array}$} & SPI & (5) & $222 \pm 134$ & $166 \pm 88$ & $132 \pm 76$ & $134 \pm 54$ & $140 \pm 77$ \\
\hline & Fish & (7) & $95 \pm 21$ & $90 \pm 23$ & $93 \pm 22$ & $96 \pm 17$ & $90 \pm 18$ \\
\hline & Mix. & (8) & $93 \pm 12$ & $90 \pm 21$ & $97 \pm 15$ & $97 \pm 23$ & $85 \pm 13$ \\
\hline \multirow{3}{*}{$\begin{array}{l}\text { Total } \\
\text { cholesterol } \\
(\mathrm{mg} / 100 \mathrm{ml})\end{array}$} & SPI & (5) & $178 \pm 20$ & $151 \pm 21$ & $152 \pm 29$ & $150 \pm 23$ & $146 \pm 13$ \\
\hline & Fish & (7) & $144 \pm 14$ & $147 \pm 13$ & $141 \pm 15$ & $136 \pm 8$ & $142 \pm 21$ \\
\hline & Mix. & (8) & $145 \pm 23$ & $127 \pm 11$ & $130 \pm 16$ & $136 \pm 16$ & $131 \pm 6$ \\
\hline \multirow{3}{*}{$\begin{array}{l}\mathrm{Na} \\
(\mathrm{mEq} / \text { liter })\end{array}$} & SPI & (5) & $143 \pm 1$ & $142 \pm 1$ & $142 \pm 2$ & $142 \pm 2$ & $142 \pm 2$ \\
\hline & Fish & (7) & $142 \pm 5$ & $138 \pm 3$ & $135 \pm 4$ & $136 \pm 4$ & $137 \pm 5$ \\
\hline & Mix. & (8) & $140 \pm 2$ & $137 \pm 3$ & $135 \pm 4$ & $136 \pm 6$ & $138 \pm 4$ \\
\hline \multirow{3}{*}{$\begin{array}{l}\text { K } \\
(\mathrm{mEq} / \text { liter })\end{array}$} & SPI & (5) & $4.2 \pm 0.5$ & $4.1 \pm 0.3$ & $4.1 \pm 0.3$ & $4.2 \pm 0.2$ & $4.0 \pm 0.3$ \\
\hline & Fish & (7) & $4.2 \pm 0.5$ & $3.9 \pm 0.3$ & $3.9 \pm 0.3$ & $3.9 \pm 0.5$ & $3.8 \pm 0.2$ \\
\hline & Mix. & (8) & $4.5 \pm 0.8$ & $4.0 \pm 0.4$ & $4.1 \pm 0.8$ & $4.0 \pm 0.3$ & $4.0 \pm 0.3$ \\
\hline
\end{tabular}

Appendix 5. Urinalysis.

\begin{tabular}{|c|c|c|c|c|c|c|}
\hline & \multirow{2}{*}{\multicolumn{2}{|c|}{$\begin{array}{l}\text { Protein } \\
\text { source }\end{array}$}} & \multicolumn{4}{|c|}{ Protein level $(\mathrm{g} / \mathrm{kg})$} \\
\hline & & & 0.35 & 0.45 & 0.55 & 0.65 \\
\hline \multirow{3}{*}{$\begin{array}{l}\text { Creatinine } \\
\text { (g/day) }\end{array}$} & SPI & $(5)$ & $1.57 \pm 0.25$ & $1.59 \pm 0.23$ & $1.59 \pm 0.22$ & $1.62 \pm 0.25$ \\
\hline & Fish & (7) & $1.56 \pm 0.12$ & $1.58 \pm 0.09$ & $1.61 \pm 0.12$ & $1.59 \pm 0.13$ \\
\hline & Mix. & (8) & $1.56 \pm 0.08$ & $1.57 \pm 0.09$ & $1.58 \pm 0.08$ & $1.59 \pm 0.09$ \\
\hline \multirow{3}{*}{$\begin{array}{l}\text { Urea-N } \\
\text { (g/day) }\end{array}$} & SPI & (5) & $3.06 \pm 0.61$ & $3.72 \pm 0.65$ & $4.32 \pm 0.76$ & $4.79 \pm 0.85$ \\
\hline & Fish & (7) & $2.10 \pm 0.47$ & $2.61 \pm 0.44$ & $3.05 \pm 0.54$ & $3.82 \pm 0.36$ \\
\hline & Mix. & (8) & $2.09 \pm 0.40$ & $2.72 \pm 0.37$ & $3.26 \pm 0.51$ & $3.58 \pm 0.49$ \\
\hline \multirow{3}{*}{$\begin{array}{l}\text { Ammonia-N } \\
\text { (mg/day) }\end{array}$} & SPI & (5) & $270 \pm 60$ & $300 \pm 70$ & $340 \pm 80$ & $350 \pm 70$ \\
\hline & Fish & (7) & $290 \pm 83$ & $317 \pm 55$ & $329 \pm 62$ & $337 \pm 44$ \\
\hline & Mix. & (8) & $284 \pm 76$ & $302 \pm 57$ & $308 \pm 77$ & $312 \pm 76$ \\
\hline \multirow{3}{*}{$\begin{array}{l}\text { Uric acid } \\
(\mathrm{mg} / \text { day })\end{array}$} & SPI & (5) & $500 \pm 60$ & $550 \pm 90$ & $570 \pm 90$ & $620 \pm 110$ \\
\hline & Fish & (7) & $483 \pm 50$ & $494 \pm 61$ & $500 \pm 32$ & $514 \pm 27$ \\
\hline & Mix. & (8) & $439 \pm 67$ & $483 \pm 69$ & $526 \pm 95$ & $527 \pm 45$ \\
\hline \multirow{3}{*}{$\begin{array}{l}\mathrm{Na} \\
(\mathrm{g} / \text { day })\end{array}$} & SPI & & - & - & - & - \\
\hline & Fish & (7) & $3.07 \pm 0.53$ & $3.35 \pm 0.52$ & $3.64 \pm 0.42$ & $3.91 \pm 0.39$ \\
\hline & Mix. & (8) & $2.79 \pm 0.47$ & $3.27 \pm 0.62$ & $3.39 \pm 0.47$ & $3.60 \pm 0.71$ \\
\hline \multirow{3}{*}{$\mathrm{K}_{\text {(g/day) }}$} & SPI & & 二 & - & - & - \\
\hline & Fish & (7) & $1.04 \pm 0.27$ & $1.13 \pm 0.37$ & $1.15 \pm 0.39$ & $1.23 \pm 0.42$ \\
\hline & Mix. & (8) & $1.01 \pm 0.31$ & $1.02 \pm 0.33$ & $1.04 \pm 0.29$ & $1.04 \pm 0.35$ \\
\hline
\end{tabular}

